\title{
Water requirements and irrigation scheduling of maize in Northern Gangetic plains
}

\section{Rakesh Kumar and Rajkumar Jat}

Received : 04.01.2018; Revised : 05.03.2018; Accepted : 17.03.2018

See end of the Paper for authors' affiliation

Correspondence to :

Rakesh Kumar School of Ecology and Environmental Studies, Nalanda University, Rajgir, Nalanda, (Bihar) India

Email : rakumar.sees17@ nalandauniv.edu.in
-ABSTRACT : The irrigation requirements for different crops varies from climatic conditions and soil types. The study was conducted to determine irrigation requirement and irrigation scheduling for maize. The irrigation efficiency and field efficiency of 80 per cent and 70 per cent were considered for the study, respectively. The average ET calculated was 3.77 and $3.63 \mathrm{~mm} /$ dayfor 2015 and 2016, respectively. The total irrigation requirement for maize was 171 and $118.4 \mathrm{~mm}$ for both 50 per cent and 60 per cent critical depletion regarding 2015 and 2016, respectively.The total gross irrigation and net irrigation was $128.9 \mathrm{~mm}$ and $90.3 \mathrm{~mm}$ for 50 per cent critical depletion and $159.2 \mathrm{~mm}$ and $111.4 \mathrm{~mm}$ for 60 per cent critical depletion in 2015 while total gross irrigation and net irrigation was $128.6 \mathrm{~mm}$ and $90.0 \mathrm{~mm}$ for 50 per cent critical depletion and $156.0 \mathrm{~mm}$ and $119.2 \mathrm{~mm}$ for 60 per cent critical depletion in 2016.The rain efficiency was found 25.6 per cent and 39.4 per cent and by this efficiency, effective rainfall was $179.1 \mathrm{~mm}$ and $219.5 \mathrm{~mm}$ for 2015 and 2016, respectively.

- KEY WORDS : Maize, Critical depletion, Irrigation requirements, Gangetic plains, Irrigation efficiency

- HOW TO CITE THIS PAPER : Kumar, Rakesh and Jat, Rajkumar (2018). Water requirements and irrigation scheduling of maize in Northern Gangetic plains. Internat. J. Agric. Engg., 11(1) : 210215, DOI: 10.15740/HAS/IJAE/11.1/210-215. 